\title{
The impacts of the lack of ergonomic vision in mining equipment design projects on the health of workers in the maintenance sector
}

\author{
Os impactos da falta de visão ergonômica em projetos de design de equipamentos de mineração na \\ saúde dos trabalhadores do setor de manutenção
}

Los impactos de la falta de visión ergonómica en los proyectos de diseño de equipos de minería en la salud de los trabajadores del sector de mantenimiento

Received: 10/18/2021 | Reviewed: 10/25/2021 | Accept: 10/26/2021| Published: 11/02/2021

\author{
Aparício Afonso dos Santos \\ ORCID: https://orcid.org/0000-0002-5308-6026 \\ Universidade Federal de Ouro Preto, Brazil \\ aparicio.santos@aluno.ufop.edu.br \\ Luciana Paula Reis \\ ORCID: https://orcid.org/0000-0002-6009-8674 \\ Universidade Federal de Ouro Preto, Brazil \\ lucianapaula@ufop.edu.br
}

\begin{abstract}
This study aims to analyze the impacts of the lack of ergonomic view in the projects of equipment design on workers' health from the maintenance sector, in the mining industry context. To understand the operators' health, maintenance activities of three types of equipment were analyzed: pump, crusher and sieve. The methodological strategy of Ergonomic Analysis of the Workplace (EWA) was used. Thus, changes in these activities are required, since some postures adopted for their performance were considered severe and with high risk. Bearing weight above the shoulders and uncomfortable positions are conditions resulted from failures in the equipment designs. To alleviate the problem, it is suggested the adoption of innovative tools or the creation of new supportive devices to improve working conditions of these maintenance professionals.
\end{abstract}

Keywords: Activity-centered ergonomics; Equipment maintenance; Mining equipment design.

\begin{abstract}
Resumo
Este estudo tem como objetivo analisar e compreender possíveis influências da ausência de visão ergonômica na concepção dos projetos de equipamentos, na saúde dos trabalhadores do setor de manutenção, no contexto de uma indústria de mineração. Observa-se que lesões no sistema osteomuscular foram responsáveis por 63,45\% dos afastamentos na indústria brasileira no ano de 2018. Por meio de uma análise ergonômica do trabalho (AET), foram analisadas as atividades de manutenção de três equipamentos: bomba, britador e peneira. Assim, verificou-se a necessidade de efetuar mudanças nessas atividades, uma vez que algumas posturas adotadas para a sua realização foram consideradas de grande risco e grave severidade. Suportar peso acima dos ombros e posições incômodas, são condições decorrentes de falhas na concepção desses equipamentos. Para atenuar o problema, sugere-se o emprego de ferramentas de inovação ou criação de novos dispositivos de apoio para melhoria das condições do trabalho desses profissionais de manutenção.
\end{abstract}

Palavras-chave: Ergonomia centrada na atividade; Manutenção de equipamentos; Projetos de equipamentos de mineração.

\section{Resumen}

Este estudio tiene como objetivo analizar y comprender las posibles influencias de la ausencia de visión ergonómica en el diseño de proyectos de equipos, sobre la salud de los trabajadores del sector de mantenimiento, en el contexto de una industria minera. Se observa que las lesiones del aparato locomotor fueron responsables del 63,45\% de las bajas laborales en la industria brasileña en 2018. Mediante un análisis ergonómico del trabajo (AET), se analizaron las actividades de mantenimiento de tres equipos: bomba, trituradora y criba. Por lo tanto, existía la necesidad de realizar cambios en estas actividades, ya que algunas posturas adoptadas para su desempeño fueron consideradas de gran riesgo y gravedad. Soportar peso por encima de los hombros y posiciones incómodas son condiciones derivadas de fallas en el diseño de estos equipos. Para paliar el problema, se sugiere el uso de herramientas de innovación o la creación de nuevos dispositivos de soporte para mejorar las condiciones de trabajo de estos profesionales de mantenimiento.

Palabras clave: Ergonomía centrada en la actividad; Mantenimiento de equipos; Proyectos de equipos de minería. 


\section{Introduction}

The mining sector deals with several types of equipment whose designs come from a time when ergonomics was not a major concern (Jasiulewicz-Kaczmarek \& Drozymer, 2013). The lack of ergonomic perspective in the design of the pieces of equipment, without the participation of the "conception actors" (Daniellou, 2007), provides working conditions that are harmful to the health of the maintenance teams. Thus, operators are exposed to noise, vibration, heat and muscle fatigue that generate serious ergonomic problems (Leite et al., 2003). Among them, Work-Related Musculoskeletal Disorders (WMSDs) and Repetitive Strain Injuries (RSI) are stand out (Bulduk et al., 2017; Nadri et al., 2015). Once conceived without an ergonomic perspective, the equipment maintenance acquire a decisive status in the operators' illness process.

Searches carried out in academic databases did not identify in the literature studies that relate the lack of an ergonomic perspective in the equipment design and the illness problems of maintenance teams, especially addressing the mining sector. Studies found address this relationship, however in other industrial contexts (Jasiulewicz-Kaczmarek \& Drozymer, 2013), but not focusing on mining equipment as in this article. On the other hand, studies focused on mining address the maintenance management and reliability analysis of these pieces of equipment (Fore \& Msipha, 2012; Bascur \& Kennedy, 2002), or the use of standards that address ergonomic issues of industrial equipment operators (McPhee, 2004), without mentioning this relationship. It is highlighted that with automation, machine learning and other technologies, many pieces of equipment have become autonomous, and man-machine interaction has become more evident in their maintenance. These changes lead to the need to consider the perception of the "design actors" during the design phase of the equipment, to ergonomic teams find measures that eliminate or at least minimize the negative ergonomic impacts to the operators, during the execution of their maintenance tasks.

Ergonomics applied to equipment design (Ishwarya \& Rajkumara, 2020; Carballeda, 1997) aims to find a way to work focused on maintaining the operators' health and safety (Daniellou, 2004; Dejours \& Deranty, 2010). Daniellou (2004) states that ergonomics does not see man as an adjustable variable. It is the equipment that must adjust, complement man's strengths and abilities, minimizing the negative effects of work on their health (Daniellou, 2007).

To enable the equipment design, Daniellou (2007) proposes the perspective of Future Activity Analysis (FAA). The FAA seeks to solve the ergonomist's difficulty in assessing risk situations, identifying existing situations (reference situations) that may clarify the conditions of future activity (Béguin, 2007; Daniellou \& Garrigou, 1992). The FAA in equipment projects contributes positively to risk management and mitigates negative ergonomic impacts on the operators' health.

The lack of an ergonomic perspective in equipment design (Jasiulewicz-Kaczmarek \& Drozymer, 2013) leads workrelated illnesses to get worse and worse (Bulduk et al., 2017; Nadri et al., 2015). This worsening can be observed in the maintenance activity in mining industry, which includes a set of complex and risky tasks (Amalberti, 1996). This activity involves different equipment that require a specialization of the task to carry out this activity. Design flaws lead to operating modes in dissonance with the activity prescription, generating ergonomic risks, due to the worker's exposure to situations of postures and movements that lead the human body beyond its limit (Daniellou et al., 1989).

Even with the increasingly mechanization and automation of these complex activities, they continue comprising a set of manual tasks (Huysamen et al., 2018; Nadri et al., 2015) that intensify the damage to workers' health. WMSDs, for example, were responsible for removing 349,050 individuals from the workforce worldwide in 2016, according to the data released in 2018 by the Bureau of Labor Statistics. Besides WMSD, other losses are present such as exhaustion, overworkload and absence from work (Paula et al., 2016; Nadri et al., 2015), herniated disc, back pain (Bulduk et al., 2017), varicose veins, among others.

In this context, this study aims to analyze the impacts of the lack of an ergonomic view during equipment design on workers' health from the maintenance sector in a mining industry. The search for understanding this issue is justified by the need 
to investigate the causes of sick absence from work due to WMSD arose from this lack of an ergonomic view during the design of these pieces of equipment.

For the development of this research, it was used the Ergonomic Workplace Analysis (EWA). EWA allows us to understand the work activity, causes and progression of WMSDs (Sharan, 2012). Ergonomics focused on activity analysis seeks to improve working methods to promote changes in the conditions to perform activities (Laville, 2007; Montmollin, 2007; Guérin et al., 2001). The mobilization of the operators' knowledge in the work analysis, added to the ergonomist's knowledge, broaden the power to act on the work. Every intervention at work is a reciprocal learning situation, between the ergonomist and the operator, in which both build new knowledges (Lacomblez \& Teiger, 2007).

The activities observation was guided through 11 out of 37 design guidelines proposed by Mulder et al. (2012). As a supportive tool, the Rapid Upper Limb Assessment (RULA) was used to assess the risk of WMSD regarding postures and movements. Thus, it is expected that, from the observation of equipment design failures through these guidelines, it might be possible to identify the ergonomic impacts suffered by maintenance teams in the mining sector. It is also expected the development of working environment conditions that focus on health, operators' safety and the minimization of occupational diseases (Więcek -Janka, 2011; Cruz, 2010; Braga, 2007) in the context studied.

Studies show that in the impossibility of changing equipment designs, companies can use technological devices to mitigate this problem. The equipment design failures analysis can facilitate the development of these devices, contributing to the mitigation of maintenance impacts on operators' ergonomic issues. Among these devices, the use of robots to aid the execution of activities stands out (Huysamen et al., 2018), collaborative interaction activity between humans and robots (Figueredo et al., 2020; kim et al., 2020), wearable devices, sensors, and robotic technologies, including exoskeletons (De Looze et al., 2016), the use of virtual reality and augmented reality (Qian et al., 2018), and gamification (Nor et al., 2020; Olszewski et al., 2018). Therefore, the current research is set as a step towards the implementation of maintenance 4.0 in the studied context.

\section{Methodology}

EWA seeks to understand the tasks' performance to provide improvements in working methods and thus promote changes in the conditions to perform activities (Guérin, 2001). EWA seeks to assess the factors that can directly or indirectly affect the emerging of musculoskeletal diseases such as RSI and WMSD (Sharan, 2012).

Based on the concepts adopted to carry out an EWA, this study was divided into i) task analysis, ii) activity analysis and iii) recommendations (validations). The first steps correspond to data collection, namely: demand analysis, analysis of prescribed work and activity, respectively. The final steps focused on generating a diagnosis of failures in the equipment design that caused ergonomic problems. Finally, technological trends were presented to mitigate ergonomic problems arising from equipment design failures.

The task analysis stage began collecting statistical data regarding sickness absence due to WMSD, between the years 2018 and 2020. The data were obtained from the occupational medicine sector of the studied company. These data were compared to those from the Brazilian Department of Labor for the year 2018.

Also at this stage, to analyze the prescribed work, data from three pieces of equipment were analyzed: pumps, crushers and sieves, in order to relate the reasons for the absence from work with the deficiencies of projects in the mining equipment. These pieces of equipment were chosen due to their importance for the production process. For data collection, meetings were held with the maintenance sectors of these three equipment, to describe the steps to execute the prescribed tasks. As a baseline to perform the initial stages of the research, as for individual interviews as for written questionnaires (appendix A and B), the questions presented in Table 1 were used. In addition, it was used a form that assesses their perception regarding 11 out of the 
37 guidelines of equipment design projects proposed by Mulder et al. (2012). With this, we understood the interviewees profile, the absence reasons and what their perception of the maintained equipment was.

Table 1. Inputed informations on the interviews and questionnaires.

\begin{tabular}{|l|l|}
\hline \multicolumn{1}{|c|}{ Item } & \multicolumn{1}{c|}{ Description } \\
\hline Personal information & Age, weight, gender, education and years with the company \\
\hline $\begin{array}{l}\text { Assessment of prescribed and performed } \\
\text { activities }\end{array}$ & $\begin{array}{l}\text { Do you notice any ergonomic problems in the equipment design? If so, what are the } \\
\text { equipment failures? What kind of discomfort do they cause while performing the activity? } \\
\text { Does this lack of an ergonomic view impact on the execution time of the activities? What } \\
\text { would the consequences be of these design flaws on your health? }\end{array}$ \\
\hline
\end{tabular}

Source: Authors.

60 operators were interviewed (30 pump operators, 10 crusher operators, 20 sieve operators and). 30 of them belongs to the 258 employees who were absent from work during this analyzed period. These interviews were conducted in the company's training room and each one lasted about 30 minutes.

The interviews were recorded and transcribed for analysis. The data were arranged in tables that aimed to know the problems faced by the operators, their perception of risk and the respective defense strategies used to prevent accidents, injuries and other work-related illnesses. The activities were recorded by taking notes during the maintenance activities, randomly documenting professionals who whether were carrying out maintenance activities or developing preparation activities.

For the activity analysis stage, through monitoring and observation of maintenance activities, with photographic reports and notes, it was possible to obtain parameters from the operators' perspective in relation to the premises supported by Mulder et al. (2012), regarding equipment projects. We also analyzed: 1) postures and movements, 2) duration of activity cycles and 3 ) risk and severity of accidents.

In the recommendation stage, it was made the correlation between the identified ergonomic problems and the failures in the equipment design that lead to safety and health problems for operators. This stage consists in answering the research problem through the study objective, which is to analyze the impacts of the lack of an ergonomic view during the equipment design on workers' health from the maintenance sector in a mining industry.

At the end of this stage, the study addresses necessary ergonomic recommendations and possible technological devices to be implemented following innovation trends applied as best practices worldwide.

\section{EWA development}

\subsection{Statistical analysis on absences from work for musculoskeletal problems}

In 2018, the Brazilian Department of Labor presented statistical data regarding absence from work that lasted more than 15 days, either due to accidents or illness. From a total of benefits granted for accidents and occupational illness, out of 196,754 hours, $63.45 \%$ are related to problems concerning the musculoskeletal system.

In the company studied, the number came close to this value, with $61.98 \%$ in the year of 2020 . Thus, a very similar behavior can be seen among the main reasons for absence from work. It is observed that both the company and Brazilian Department of Labor present musculoskeletal system injuries as one of the main sources of work absences. Table 2 presents data from the occupational medicine department of the studied company, regarding the reasons for absence from work due to musculoskeletal injuries. 
Table 2.Stratification of the top five reasons for sick work absence.

\begin{tabular}{|c|c|c|c|c|c|}
\hline \multicolumn{2}{|l|}{2018} & \multicolumn{2}{|l|}{2019} & \multicolumn{2}{|l|}{2020} \\
\hline $\begin{array}{c}\text { Annual average of } \\
\text { musculoskeletal problems }(\%)\end{array}$ & 39,18 & $\begin{array}{c}\text { Annual average of } \\
\text { musculoskeletal problems } \\
(\%)\end{array}$ & 47,85 & $\begin{array}{c}\text { Annual average of } \\
\text { musculoskeletal problems } \\
(\%)\end{array}$ & 61,98 \\
\hline $\begin{array}{c}\text { Other intervertebral disc } \\
\text { disorders }\end{array}$ & 40,72 & $\begin{array}{c}\text { Other acquired member } \\
\text { deformities }\end{array}$ & 21,44 & $\begin{array}{c}\text { Other acquired member } \\
\text { deformities }\end{array}$ & 31,12 \\
\hline $\begin{array}{c}\text { Other joint disorders not } \\
\text { classified elsewhere }\end{array}$ & 16,48 & $\begin{array}{c}\text { Other joint disorders not } \\
\text { classified elsewhere }\end{array}$ & 21,34 & Coxarthrosis (hip arthrosis) & 26,91 \\
\hline Back pain & 16,38 & Back pain & 18,89 & Back pain & 22,69 \\
\hline $\begin{array}{l}\text { Acquired deformities of the } \\
\text { fingers and toes }\end{array}$ & 7,64 & Coxarthrosis (hip arthrosis) & 16,90 & $\begin{array}{c}\text { Other intervertebral disc } \\
\text { disorders }\end{array}$ & 12,15 \\
\hline Shoulder injuries & 6,99 & $\begin{array}{c}\text { Other intervertebral disc } \\
\text { disorders }\end{array}$ & 14,35 & Internal Knee Disorders & 5,22 \\
\hline
\end{tabular}

Source: Authors.

Between the years 2018 to 2020, it was possible to notice an increase in the annual average, peaking in 2020, with $61.98 \%$ of sickness absences related to the musculoskeletal system. There was a constancy in back pain injuries throughout the analyzed period, taking the third place, in addition to the problem "Other acquired member deformities " occupies the first place in the years 2019 and 2020.

\subsection{Prescribed task analysis}

Understanding the maintenance dynamics of the studied pieces of equipment and their characteristics can help to understand how their project design influence the ergonomic problems presented in this work.

Centrifugal pumps are used to transport fluids by converting the kinetic energy of rotation to the hydrodynamic energy of the fluid flow. In their maintenance, due to their size, the connections with the discharge pipes are above the shoulder line. This implies the need to remain for a long time with arms raised, bearing the weight of the tools used in the disassembly of the piece, causing discomfort in the musculoskeletal system.

Crushers are machines used to reduce the size of rocks and stones. For their maintenance, due to their dimensions, it is necessary to handle heavy parts and tools, which promote great efforts in the musculoskeletal system of maintenance teams.

Sieves are equipment used in the process of classifying materials by their particle size. In their maintenance, it is necessary to get into the sieve, which promotes the need to perform tasks in a crouched position, causing discomfort in the musculoskeletal system.

In order to evaluate the maintenance task, the perception of 60 operators from the company regarding the assumptions for designing equipment projects adopted by Mulder et al. (2012) was analyzed. Regarding the demographic data of the interviewed sample, it was possible to observe that the interviewees are exclusively men, $40 \%$ are aged between 31 and 40 years. Also, $40 \%$ of the intervewees have beteween 15 and 30 years in the company, $46.7 \%$ are between 1.70 to $1.75 \mathrm{~m}$ height and $40 \%$ between 75 and $85 \mathrm{~kg}$. Regarding education, $60 \%$ of them have completed high school and $53.3 \%$ were absent for more than 10 days. 
Table 3 presents the results obtained through the assessment made by the interviewees regarding the ability to maintain itself, reliability and supportability of the pieces of equipment, according to the initial stages of the proposed EWA.

Table 3.Operators' perception regarding the design assumptions adopted by Mulder et al. (2012).

\begin{tabular}{|c|c|c|c|c|c|c|c|c|}
\hline \multirow{3}{*}{ Item } & \multirow{3}{*}{ Description } & \multirow{2}{*}{\multicolumn{2}{|c|}{$\begin{array}{c}\text { Pumps } \\
\text { Status(\%) }\end{array}$}} & \multirow{2}{*}{\multicolumn{2}{|c|}{$\begin{array}{c}\text { Crushers } \\
\text { Status(\%) }\end{array}$}} & \multirow{2}{*}{\multicolumn{2}{|c|}{\begin{tabular}{c|c|} 
Sieves \\
Status(\%)
\end{tabular}}} & \multirow{3}{*}{$* \square \mathbf{N}$} \\
\hline & & & & & & & & \\
\hline & & $\mathbf{Y}$ & $\mathbf{N}$ & $\mathbf{Y}$ & $\mathbf{N}$ & $\mathbf{Y}$ & $\mathbf{N}$ & \\
\hline \multirow{6}{*}{ 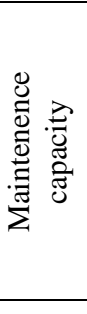 } & Design provides enough space around maintenance points. & 40,0 & 60,0 & 33,3 & 66,7 & 46,7 & 53,3 & 60,0 \\
\hline & $\begin{array}{l}\text { The project design only allows the equipment to be maintained } \\
\text { correctly }\end{array}$ & 60,0 & 40,0 & 53,3 & 46,7 & 46,7 & 53,3 & 46,7 \\
\hline & Components that are regularly replaced are easy to handle. & 26,7 & 73,3 & 13,3 & 86,7 & 40,0 & 60,0 & 73,3 \\
\hline & There is a safety guarantee by the design itself. & 20,0 & 80,0 & 6,7 & 93,3 & 33,3 & 66,7 & 80,0 \\
\hline & $\begin{array}{l}\text { The design places components that often need to be maintained in an } \\
\text { easily accessible location. }\end{array}$ & 26,7 & 73,3 & 33,3 & 66,7 & 40,0 & 60,0 & 66,7 \\
\hline & The design places maintenance points next to each other. & 53,3 & 46,7 & 26,7 & 73,3 & 53,3 & 46,7 & 55,6 \\
\hline & Assessment average & 37,8 & 62,2 & 27,7 & 72,2 & 43,3 & 56,7 & 63,7 \\
\hline \multirow[t]{2}{*}{ 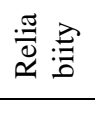 } & The project envisions a design for low-strength use. & 20,0 & 80,0 & 6,7 & 93,3 & 26,7 & 73,3 & 82,2 \\
\hline & Assessment average & 20,0 & $\mathbf{8 0 , 0}$ & 6,7 & $\mathbf{9 3 , 3}$ & 26,7 & $\mathbf{7 3 , 3}$ & 82,2 \\
\hline \multirow{5}{*}{ 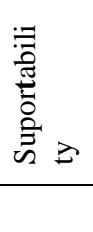 } & The project prevents secondary tasks from consuming too much time.. & 6,7 & 93,3 & 20,0 & 80,0 & 33,3 & 66,7 & 80,0 \\
\hline & It was designed to use standard tools. & 60,0 & 40,0 & 13,3 & 86,7 & 66,7 & 33,3 & 53,3 \\
\hline & $\begin{array}{l}\text { The design ensures that as few techniques as possible are required to } \\
\text { perform a maintenance task. }\end{array}$ & 66,7 & 33,3 & 20,0 & 80,0 & 60,0 & 40,0 & 51,1 \\
\hline & The project provides understandable maintenance instructions. & 73,3 & 26,7 & 46,7 & 53,3 & 60,0 & 40,0 & 40,0 \\
\hline & Assessment average & 51,7 & 48,3 & 25,0 & 75,0 & 55,0 & 45,2 & 61,7 \\
\hline
\end{tabular}

Note. $* \square \mathrm{N}-$ negative opinion averages $(\mathrm{N})$. Source: Authors.

Given the results of the interviews, it is observed that the majority of the interviewees confirm the lack of ergonomic vision in the project design, making their activity of keeping the equipment working harmful to their health. According to the data obtained, it shows that the Reliability criterion is the one that most represents the absence of ergonomic vision during the equipment design. This criterion has a rejection of $80.0 \%$ in crushers, $93.3 \%$ in pumps and $73.3 \%$ in sieves. Among the pieces of equipment, activities in crushers were considered more fragile in terms of ergonomics, with $75.0 \%$ rejection among operators.

In the initial stages of the proposed EWA yet, table 4 presents the main difficulties of the maintenance task, which offer risks to operators' health. These difficulties were raised from the RULA posture assessment tool. RULA was developed to assess workers' exposure to ergonomic risk factors associated with upper limb WMSD. RULA, as an ergonomic assessment tool, considers biomechanical and postural load, task requirements and work demands on the neck, trunk and upper extremities (Joshi \& Deshpande, 2021).

Table 4.Difficulties in the maintenance task which offer health risks.

\begin{tabular}{|c|c|c|c|}
\hline Maintenance activities difficulties & Pumps & Crushers & Sieves \\
\hline Bear tools and components weight & $18 \%$ & $23 \%$ & $9 \%$ \\
\hline Bear tools above the shoulders & $22 \%$ & $12 \%$ & $6 \%$ \\
\hline Difficult accessibility to maintenance points & $18 \%$ & $24 \%$ & $28 \%$ \\
\hline Uncomfortable working position & $9 \%$ & $25 \%$ & $30 \%$ \\
\hline Bear tools away from the body & $12 \%$ & $7 \%$ & $22 \%$ \\
\hline Use of human force to move components & $21 \%$ & $9 \%$ & $5 \%$ \\
\hline
\end{tabular}

Source: Authors. 
According to Table 4, in the interviewees' opinion, bear tools above the shoulders was the most relevant difficulty for pumps, considered by $22 \%$ of the interviewees. For crushers and sieves, the uncomfortable working positions represent the greatest difficulty, with $24 \%$ and $28 \%$ respectively. These problems understanding provides a greater comprehension of what the possible failures are arising from the projects of these equipment that cause ergonomic losses for these operators.

\subsection{Maintenance Activity Analysis}

To promote an assessment of the maintenance activity, the EWA protocol was adapted using the RULA tool. This protocol consists of data collection through a questionnaire in Check List form and systematic observation at the place where the activities are performed. For this analysis, three items were evaluated: A) postures and movements; B) duration of activity repetition cycles and C) accident risk and severity. The verification sheets address the criteria evaluated in relation to the three items, which received scores ranging from 1 to 5, being 5 a more critical grade for ergonomic problems and 1 the lightest one.

\section{Posture and movements}

Working postures refer to the positions of the neck, arms, back, hips and legs while working. Work movements are the body movements required to work. Postures and movements were evaluated during maintenance activities for the three pieces of equipment. This evaluation aims to show whether there is a relationship between the lack of ergonomic vision during equipment design on posture and on the work movements to-be performed. Within the initial stages of the proposed EWA, Table 5 presents the matrix of movement and posture classification for workplaces. 
Table 5. Matrix of movement and posture classification for workplaces.

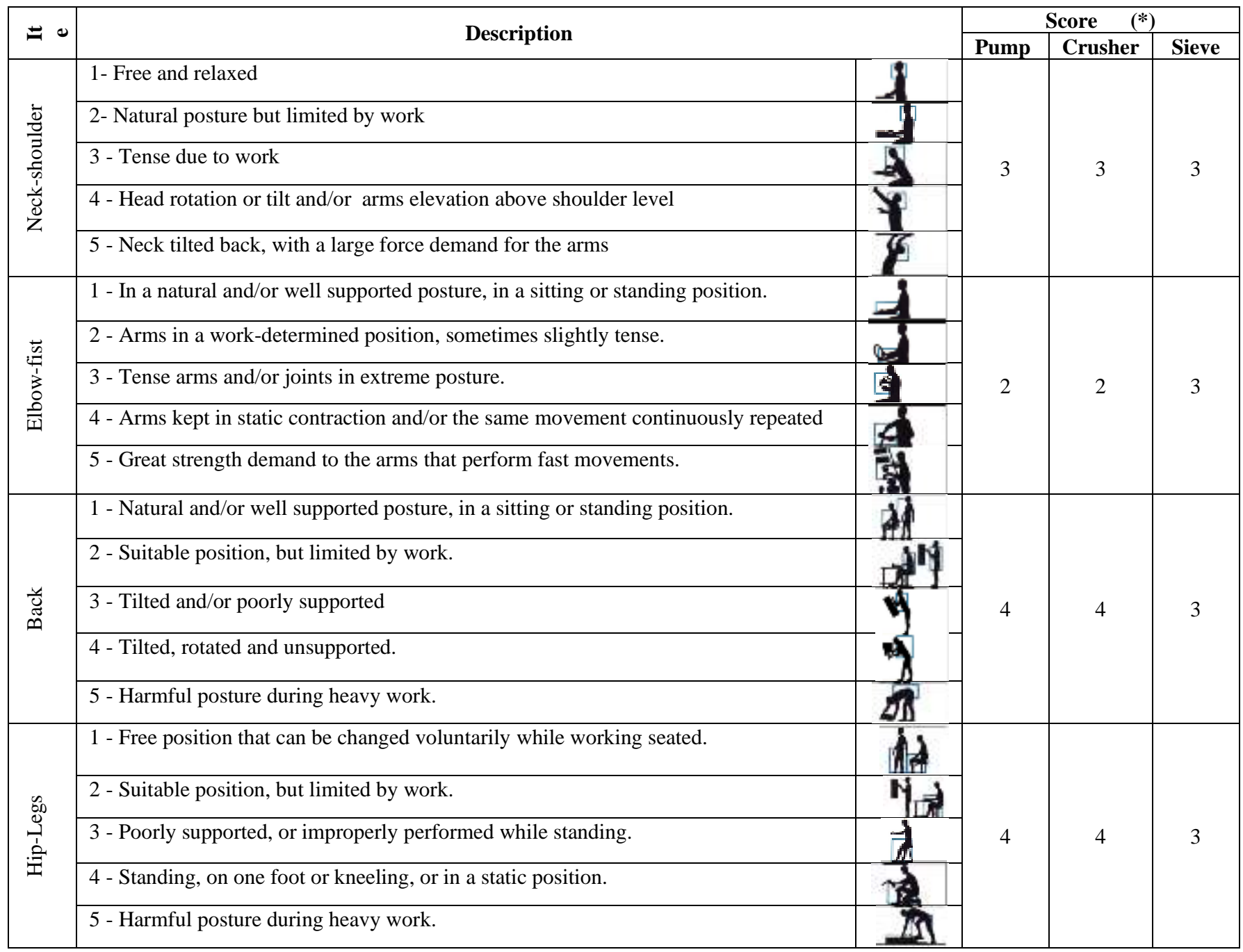

Note. Adapted from Anohem et al. (1989). *Characterization of actions by the score obtained; 1 (Acceptable) 2-3 (Changes may be necessary) 4 (Changes required) 5 (Change immediately). Source: Authors.

Analyzing Table 5, it was observed that the Back and Hip-Legs received 4, both for pumps and for the crusher. This score points to the need to make changes in the activity. These equipment maintenance conditions promote moments of tension and effort, which can contribute to injuries and illnesses for these operators.

\section{Duration of activity repetition cycles}

The work cycle is evaluated only in those activities where the task is continuously repeated and determined by the average duration of a repetitive work cycle, being measured from the beginning to the end of this cycle. Table 6 presents a classification regarding the duration of the repetitive cycle of the analyzed activities. 
Table 6. Activity repeatability cycle.

\begin{tabular}{|c|c|c|c|c|c|}
\hline \multirow{2}{*}{ Item } & \multirow{2}{*}{ Criterion } & \multirow{2}{*}{ Description } & \multicolumn{3}{|c|}{ Rating } \\
\hline & & & Pump & Crusher & Sieve \\
\hline 1 & Acceptable & more than 30 minutes & & & \\
\hline 2 & \multirow[t]{2}{*}{ Changes may be necessary } & from 10 to 30 minutes & & $\mathrm{X}$ & \\
\hline 3 & & from 5 to 10 minutes & $\mathrm{X}$ & & $\mathrm{X}$ \\
\hline 4 & Changes Required & from 30 seconds to 5 minutes & & & \\
\hline 5 & Change immediately & less than 30 seconds & & & \\
\hline
\end{tabular}

Note. Adapted from Anohem et al. (1989). Source: Authors.

In this regard, the assessment was rated between 2 and 3, pointing to the need for changes. It is noteworthy that repetitiveness under time pressure is the biggest determinant of illness at work (Fernandes, et al., 2010).

\section{Accident risks and severity}

Accident risks are related to the frequency of occurrence of the event. Severity is characterized by the magnitude of the effect. If the accident occurs, the severity is measured in terms of the operator's time of absence. Following the steps of the proposed EWA, Table 7 presents the scores for the two criteria: risk and severity.

Table 7. Risk and severity of accidents.

\begin{tabular}{|c|c|c|c|c|c|c|c|c|c|}
\hline \multicolumn{5}{|l|}{ Severity } & \multicolumn{5}{|c|}{ Risk } \\
\hline Item & $\frac{\vec{E}}{\vec{E}_{0}}$ & 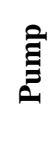 & 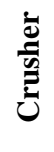 & $\sum_{i=\frac{2}{2}}$ & Item & $\frac{\vec{E}}{200}$ & 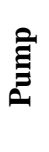 & 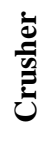 & 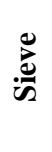 \\
\hline $\begin{array}{l}\text { The worker can avoid accidents by employing } \\
\text { normal safety procedures. No more than one accident } \\
\text { occurs every five years. }\end{array}$ & 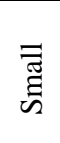 & & & & $\begin{array}{l}\text { does not cause more } \\
\text { than one day of } \\
\text { absence from work }\end{array}$ & $\frac{\overrightarrow{6}}{000}$ & & & \\
\hline $\begin{array}{l}\text { The worker avoids the accident by following special } \\
\text { instructions and being more careful and vigilant than } \\
\text { usual. It might occur one accident per year. }\end{array}$ & $\stackrel{\Xi}{\Xi}$ & & & & $\begin{array}{l}\text { causes less than a week } \\
\text { of absence from work }\end{array}$ & $\begin{array}{l}\overline{\widetilde{\Xi}} \\
\text { हี }\end{array}$ & & & \\
\hline $\begin{array}{l}\text { The worker avoids the accident by being extremely } \\
\text { careful and following safety regulations exactly. The } \\
\text { risk is apparent, and an accident might occur every } \\
\text { three months. }\end{array}$ & 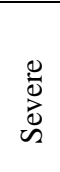 & $X$ & $X$ & $\mathrm{X}$ & $\begin{array}{l}\text { causes a month of } \\
\text { absence from work }\end{array}$ & $\frac{0}{0}$ & $X$ & $\mathrm{X}$ & $X$ \\
\hline $\begin{array}{l}\text { The worker avoids the accident by being extremely } \\
\text { careful and following safety regulations exactly. The } \\
\text { risk is apparent, and an accident might occur every } \\
\text { three months. }\end{array}$ & 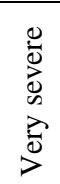 & & & & $\begin{array}{l}\text { causes at least six } \\
\text { months of absence } \\
\text { from work or } \\
\text { permanent disability. }\end{array}$ & $\stackrel{2}{>} \cdot$ & & & \\
\hline
\end{tabular}

Note. Adapted from Anohem et al. (1989). (X) score given by the respondent during the evaluation process. Source: Authors.

In terms of severity and risk, the assessment was considered severe and serious, respectively. The severity assessment in this high range points to the need for change. With the consolidation of the evaluated data, it was verified through the examiner's view that the problems related to the musculoskeletal system are the most latent ones. It was observed that the activities present risks to the health and integrity of the teams involved. 


\section{Failures Diagnosis in the Equipment Design that Cause Ergonomic Problems}

As proposed by the EWA, through the observation of the activity and with the application of the RULA posture assessment tool, the data were organized in order to present the difficulties in performing the tasks for the three pieces of equipment (Table 8).

Table 8. Perception of tasks found in maintenance activities on researched equipment.

\begin{tabular}{|c|c|c|c|}
\hline $\begin{array}{l}\text { Difficulties in the } \\
\text { activity }\end{array}$ & Pumps & Crushers & Sieves \\
\hline $\begin{array}{l}\text { Bear tools away from the } \\
\text { body }\end{array}$ & $\begin{array}{l}\text { Due to the position of the } \\
\text { suction reel (between the } \\
\text { pump casing and the slurry } \\
\text { tank), it is necessary to keep } \\
\text { the arms extended during its } \\
\text { disassembly activity. }\end{array}$ & $\begin{array}{l}\text { Due to several interferences } \\
\text { existing in the hydraulic system of } \\
\text { the crusher shaft drive, it is not } \\
\text { possible to use the tools close to } \\
\text { the body during the entire } \\
\text { maintenance period. }\end{array}$ & $\begin{array}{l}\text { The drive shaft makes it impossible for } \\
\text { the arms to be close to the fastening } \\
\text { screws, making it necessary to keep the } \\
\text { arms extended during the removal of } \\
\text { the bearing. }\end{array}$ \\
\hline $\begin{array}{l}\text { Bear tools above the } \\
\text { shoulders }\end{array}$ & $\begin{array}{l}\text { The casing dimensions (with } \\
\text { sizes greater than 14x12") } \\
\text { provide the existence of parts } \\
\text { and attachments that are } \\
\text { above shoulder height. }\end{array}$ & $\begin{array}{l}\text { During crusher crankcase } \\
\text { maintenance, many of the parts } \\
\text { and fixtures are asssembled above } \\
\text { the shoulder line. }\end{array}$ & $\begin{array}{l}\text { In casing repair operations, to reach the } \\
\text { upper sides, it is necessary to support } \\
\text { the sander and electrode holder above } \\
\text { the shoulder line. }\end{array}$ \\
\hline $\begin{array}{l}\mathrm{s} \text { and } \\
\text { nts weight }\end{array}$ & $\begin{array}{l}\text { To disassemble the pumps it is } \\
\text { necessary to use tools such as } \\
\text { pneumatic screwdrivers that } \\
\text { weigh } 25 \mathrm{~kg} \text { on average. }\end{array}$ & $\begin{array}{l}\text { To disassemble the crushers it is } \\
\text { necessary to use tools such as } \\
\text { pneumatic screwdrivers that weigh } \\
\text { a } 25 \mathrm{~kg} \text { on average, } 36 \text { " wrenches } \\
\text { and } 500 \mathrm{~kg} \text { hoists that weigh } 7 \mathrm{~kg} \\
\text { and 10kg respectively. }\end{array}$ & $\begin{array}{l}\text { In the reforms and repairs of the } \\
\text { internal structure of the sieves, as the } \\
\text { operator must be inside it, below the } \\
\text { level of fixation of the screens, it is not } \\
\text { possible to use overhead cranes. In this } \\
\text { way, the tools and parts used in this } \\
\text { operation are kept with human strength. }\end{array}$ \\
\hline $\begin{array}{l}\text { bility to } \\
\text { nts }\end{array}$ & $\begin{array}{l}\text { To disassemble the pump } \\
\text { suction it is necessary to stand } \\
\text { between the slurry tank, the } \\
\text { suction valve, the flanges and } \\
\text { the pump casing, giving } \\
\text { limited space to move. }\end{array}$ & $\begin{array}{l}\text { As in the crusher hydraulic system } \\
\text { there are many oil and water pipes. } \\
\text { To reach some parts it is } \\
\text { impossible to maintain an upright } \\
\text { posture. The operator "working } \\
\text { sideways" exposes his spine to } \\
\text { mechanical stress. }\end{array}$ & $\begin{array}{l}\text { For repairs to the main pipe and } \\
\text { channells it is necessary to get into the } \\
\text { sieve. The operator works lying down, } \\
\text { being limited in his movements. }\end{array}$ \\
\hline $\begin{array}{l}\text { Uncomfortable working } \\
\text { position }\end{array}$ & $\begin{array}{l}\text { To disassemble parts such as } \\
\text { the casing, rotor, volute wear } \\
\text { plate and pipes, it is necessary } \\
\text { to remain standing or } \\
\text { crouched during these } \\
\text { activities. }\end{array}$ & $\begin{array}{l}\text { To disassemble parts, such as the } \\
\text { hydraulic system, coating, axle, } \\
\text { among others, it is necessary to } \\
\text { remain standing or crouched } \\
\text { during these activities. }\end{array}$ & $\begin{array}{l}\text { In the maintenance of the internal } \\
\text { components of the sieves such as the } \\
\text { main pipe, channell, fastening rulers } \\
\text { and screens, it is necessary to get into } \\
\text { the sieve. The working position is lying } \\
\text { down or crouched. }\end{array}$ \\
\hline $\begin{array}{l}\text { Moving heavy } \\
\text { components and oxy- } \\
\text { fuel cutting assemblies } \\
\text { with human force }\end{array}$ & \multicolumn{3}{|c|}{$\begin{array}{l}\text { Replaced parts and oxy fuel cut sets are transported using human force, pushing a platform car for more than } \\
100 \mathrm{~m} .\end{array}$} \\
\hline
\end{tabular}

Source: Authors.

According to the data collected, from the maintenance activities observation in the three studied pieces of equipment (Table 8), it can be noticed how the interaction between the body of the maintenance teams and the equipment maintained is. Thus, it is possible to identify postures that cause effort or discomfort to the musculoskeletal system. Among the inappropriate postures, it is observed being crouched; standing for a long time; staying with arms raised above the line of the shoulders; using of human force as a way of transporting parts, among others. These postures come from the failures in these equipment design, which did not use the vision of future activity, to predict situations like these and thus outline mitigation measures.

The search for solutions to achieve the goals that provide more safety for workers in the mining industry, from the ergonomic maintenance point of view, presupposes the mobilization of professional design skills, which may involve technical areas (engineering, design, information technology, etc.) as well as the organizational structure. In this case study, it can be seen 
that the lack of "design actors", as called by Daniellou (2007), in the equipment designs involved in the study, lead to risky situations for the safety and health of workers involved in their maintenance. Reports of the difficulties encountered by these professionals, during the execution of their activities, demonstrate their dissatisfaction. Reports such as, "at the end of the day my legs are sore" (Operator 01$)^{1}$ or "it is strange how after a while with the arms up, the equipment part seems to get heavier" (Operator 02) ${ }^{1}$ or, "after crouched for a long time, when I get up I get dizzy" (Operator 03) ${ }^{1}$ or even, "the jolt that this platform cart causes in the arm, if we distract it may hurt us" (Operator 04) ${ }^{1}$. These arguments were recurrent during the interviews.

The findings show that even with studies aimed at improving the ergonomic conditions of maintenance activities, there is still a gap for studies with regard to mining equipment. These pieces of equipment were conceived in the 20th century and have presented difficulties to be modified. The use of human force, as a form of traction for vehicles to transport parts and oxy fuel cut assemblies, for example, is still part of the routine of these professionals. Thus, they need to adapt to these conditions, creating their own strategy or being affected by occupational diseases to which they are exposed to.

\section{Technological Trends to Mitigate Ergonomic Problems Arising from Equipment Design Failures}

It is verified in the study that due to the physical characteristics of the pieces of equipment, as they are large and heavy, it is necessary to make great mechanical efforts during maintenance activities. As stated in the study, these pieces of equipment, conceived in the 20th century, showed little design evolution. The evolutions given to them were mainly restricted to the use of more durable materials or improvements to promote greater operational performance. However, no changes were observed to fullfill this lack of ergonomic point of view in the equipment design, as defended by the concept of design actors (Daniellou, 2007). Thus, what is verified here is the latent need to "remedy" the problem. Working reactively, creating devices that help operators to eliminate situations that are harmful to their health, or at least reduce their exposure to these agents.

Given the difficulties found by operators, it is suggested the use of new technologies as mitigating actions. With technological advancements in the human-robot relationship, which aim to safeguard the worker's well-being while optimizing the system's productivity and performance, the exoskeleton stands out as a successful innovation (Figueredo et al., 2020; kim et al., 2020; Spada et al., 2017).

Physical assistance projects to activities with robots, cobots or wearable assistants, such as exoskeletons or assistive technology devices for physical disabilities are already a reality (Giovanelli \& Vareille, 2018). For Viteckova et al., (2013), commercially available exoskeletons have been predominantly used for rehabilitation purposes. These devices are made to support and assist physically weak, injured or disabled people with prescribed exercises and activities. De Looze et al. (2016) highlight the importance of demonstrating the effectiveness and safety of these technologies in order to support their uptake by industry.

It can also be mentioned the fixed or mobile base manipulators very widespread in the automotive sector, as a way of solving the anti-ergonomic weight-bearing conditions to which these operators are subjected (Katz et al., 2006). The application of Automatically Guided Vehicles (AGV) to transport parts is also a reality in other industrial sectors and can be a solution for eliminating human force in the activity of transporting tools and parts (Das, 2016). There are also mechanical weight canceling devices that, through reactions by springs or counterweights, are capable to eliminate human-induced weight bearing (Yamada et al., 2011).

Therefore, using these technologies presented can be a way to remedy the ergonomic deficiencies found in the equipment design studied in this article, in order to contribute to improve the mining operators' health condition. According to the final stage of the proposed EWA and, given the study trends mentioned for mitigating the reported problems, the study points to some technologies capable to mitigate the negative effects on the operators' health during the maintenance activity (Table 9). 
Table 9.Trend suggestions as a mitigation solution for ergonomic risks.

\begin{tabular}{|l|l|}
\hline Difficulty found in the activity & Pumps/ Crushers/ Sieves \\
\hline Bear tools and components weight & Exoskeletons (Viteckova et al., 2013); Weight cancellers (Yamada et al., 2011). \\
\hline Bear tools above the shoulders & $\begin{array}{l}\text { Active exoskeletons (De Looze } \text { et al., 2016); Weight cancellers (Yamada } \text { et al., } \\
2011) .\end{array}$ \\
\hline Difficult accessibility to maintenance points & Robots (Giovanelli \& Vareille, 2018). \\
\hline Uncomfortable working position & Exoskeletons (Viteckova et al., 2013). \\
\hline Bear tools away from the body & Manipulator arms (Katz, et al., 2006); Weight cancellers (Yamada et al., 2011). \\
\hline Use of human force to move components & Supportive vehicles (Das, S. K., 2016). \\
\hline
\end{tabular}

Source: Authors.

It is verified, according to Table 9, that these technologies can be applied with the intention of favoring ergonomic conditions in the maintenance of the three pieces of equipment in the study. Exoskeletons, manipulator arms and weight cancellers can all contribute to weight problems and unpleasant positions for the human body. Finally, robots can replace humans in hard-to-reach places, and supportive vehicles contribute to the use of human force to transport parts and tools.

\section{Conclusions}

This research aimed to assess the impacts of the lack of an ergonomic perspective in the equipment design on the maintenance operators' health, in a mining industry context. For Bolis et al. (2020) one of the main goals of ergonomics is to transform work processes into a deeper understanding and involvement of workers.

To gather data about ergonomic factors of the maintenance activity, a survey questionnaire was conducted among workers in the mining maintenance sector. This approach allowed workers to participate in the improvement, as they are the main focus of this study.

During the data analysis phase, there was a convergence between data from the Brazilian Department of Labor and the company studied. According to data from the Brazilian Department of Labor, out of 196,754 hours granted due to accidents and illness at work, $63.45 \%$ of them refer to problems related to the musculoskeletal system. In the company studied, this number came close to this value, with $61.98 \%$.

According to the results of the prescribed task analysis, it was observed that tools above the shoulders were considered the greatest difficulty among $22 \%$ of pump operators. For crushers and sieves, the biggest difficulty was the uncomfortable working position, with $24 \%$ and $28 \%$ respectively.

In the activity analysis phase using the RULA tool, the Back and Hip-legs required changes were observed (both received score 4 for pumps and crusher). According to the operators' evaluation, $63.7 \%$ of them agree that there is a problem to keep the maintenance capability. Another $82.2 \%$ reject the reliability premise and $61.7 \%$ see the lack of ergonomic view in the supportability for maintenance item.

The conception of these huge pieces of equipment took place in an age when they were designed to be robust and to last for many years. Given the difficulty of modifying the designs of the studied pieces of equipment, it is suggested the use of technological solutions such as exoskeletons, collaborative robots, weight cancellers and autonomous supportive vehicles for transporting parts and tools. These solutions seek to reduce the negative impacts of equipment design failures on operators' health. They are also able to support weight, or promote rest for the musculoskeletal system of operators in crouched tasks. The use of virtual reality also represents a way to train operators in the prescribed tasks. 
Even with all the technological advancements and the coming of industry 4.0, it is clear that the maintenance sector has cutting-edge technology but it still has equipment from the first industrial revolution age. Tools such as hammers, levers, wrenches, among many other manual work still contrast with the technological advancements present in industrial maintenance 4.0. Allied to this, the lack of space to the operator poses himself during maintenance, the lack of ergonomic positions to eliminate harmful conditions to health and the weight of parts and components lead us to a worrying situation in this sector.

The research gave birth to new theoretical discussions such as the mining equipment obsolescence from the point of view of the design actors of Daniellou (2007). It also allowed for an initial proposal on how companies can improve the synergies between ergonomics and deficiencies in equipment design, in practice, through the insertion of risk mitigation devices. Hence, the current research offered a kind of diagnosis of the situation and potential for further studies development, project reviews or creation of supportive devices to improve ergonomic requirements.

As the studied pieces of equipment in the research are used in all mining companies, the research was limited to observe only a single company, showing its reality in comparison with data from the Brazilian Department of Labor and Employment. Despite this, it is observed that this problem is experienced by most companies in this sector. Another limitation is mentioned that the technologies presented here are not yet set as a reality in this sector, thus requiring an empirical validation.

For future researches, based both on the article and on the literature used, it is suggested a greater interaction of the ergonomic in the industrial equipment design stages. In this context, a new industry emerges, that creates devices that facilitate maintenance and that provide safety, ergonomics and productivity to operations. Studying the equipment design failures and proposing supportive solutions by using devices or accessories are presented as an excellent gap for further studies. The study of these solutions can improve these professionals' health as well as better operational performance of these industrial processes.

These researching lines are important for society, since the company data corroborate with data from the Brazilian Department of Labor and Employment. Furthermore, all mining companies use the same pieces of equipment. Future studies with more companies from the same field will be able to certify the impacts of the lack of ergonomic aspects in the mining equipment designs and verify the prevalence or not of the same problems mentioned here.

\section{References}

Ahonen, M., Launis, M., \& Kuorinka, T. (1989). Ergonomic Workplace Analysis-Helsinki: Institute of Occupational Health. Amalberti, R. (1996). La conduite de systèmes à risques: le travail à l'hôpital. Presses universitaires de France.

Bascur, O. A., \& Kennedy, J. P. (2002). Reducing maintenance costs using process and equipment event management. Mineral Processing Plant Design, Practice and Control, Proceedings, 507-527.

Béguin, P. (2007). O ergonomista, ator da concepção. Ergonomia, 317-330.

Bureau of Labor Statistics. (2012). Nonfatal occupational injuries and illnesses requiring days away from work, 2018.

Braga, C. D. O. (2007). Análise ergonômica do trabalho e exigências laborais em unidades de beneficiamento de tomate de mesa.

Bolis, I., Morioka, S. N., Brunoro, C. M., Zambroni-de-Souza, P. C., \& Sznelwar, L. I. (2020). The centrality of workers to sustainability based on values: Exploring ergonomics to introduce new rationalities into decision-making processes. Applied Ergonomics, 88, 103148.

Bulduk, S., Bulduk, E. Ö., \& Süren, T. (2017). Reduction of work-related musculoskeletal risk factors following ergonomics education of sewing machine operators. International journal of occupational safety and ergonomics, 23(3), 347-352.

Carballeda, G. (1997). La contribution des ergonomes à l'analyse et à la transformation de l'organisation du travail: l'exemple d'une intervention relative à la maintenance dans une industrie de processus continu (Doctoral dissertation, Paris, CNAM).

CRUZ, J. A. Análise dos fatores ergonômicos do ambiente e sua relevância para a melhoria das condições de trabalho e do clima organizacional: um estudo de caso no Fórum da Comarca de Gloria - BA. 2010. Monografia (Graduação) - Faculdade Sete de Setembro, Bahia, 2010.

Daniellou, F., \& Garrigou, A. (1992). Human Factors in design: sociotechnics or ergonomics. Design for manufacturability, 55-63.

Daniellou, F., Laville, A., \& Teiger, C. (1989). Ficção e realidade do trabalho operário. Revista Brasileira de Saúde Ocupacional, 17(68), 7-13. 
Daniellou, F. (2004). A ergonomia em busca de seus princípios debates epistemológicos. In A ergonomia em busca de seus princípios debates epistemológicos (pp. 244-244).

Daniellou, F. (2007). A ergonomia na condução de projetos de concepção de sistemas de trabalho. Ergonomia, 1.

Das, S. K. (2016). Design and methodology of line follower automated guided vehicle-a review. International Journal of Science Technology \& Engineering, 2 , 9-13.

De Looze, M. P., Bosch, T., Krause, F., Stadler, K. S., \& O’Sullivan, L. W. (2016). Exoskeletons for industrial application and their potential effects on physical work load. Ergonomics, 59(5), 671-681.

Dejours, C., \& Deranty, J. P. (2010). The centrality of work. Critical Horizons, 11(2), 167-180.

Fernandes, R. D. C. P., Assunção, A. Á., \& Carvalho, F. M. (2010). Tarefas repetitivas sob pressão temporal: os distúrbios mu sculoesqueléticos e o trabalho industrial. Ciência \& saúde coletiva, 15, 931-942.

Figueredo, L. F., Aguiar, R. C., Chen, L., Chakrabarty, S., Dogar, M. R., \& Cohn, A. G. (2020). Human Comfortability: Integrating Ergonomics and MuscularInformed Metrics for Manipulability Analysis During Human-Robot Collaboration. IEEE Robotics and Automation Letters, 6(2), $351-358$.

Fore, S., \& Msipha, A. (2010). Preventive maintenance using reliability centred maintenance (RCM): A case study of a ferrochrome manufacturing company. South African Journal of Industrial Engineering, 21(1), 207-234.

Giovanelli, Y., \& Vareille, A. (2018). Dispositif d'assistance physique pour lutter contre les troubles musculosquelettiques. Archives des Maladies Professionnelles et de l'Environnement, 79(3), 351.

Guérin, F., Kerguelen, A., \& Laville, A. (2001). Compreender o trabalho para transformá-lo: a prática da ergonomia. Editora Blucher.

Huysamen, K., de Looze, M., Bosch, T., Ortiz, J., Toxiri, S., \& O'Sullivan, L. W. (2018). Assessment of an active industrial exoskeleton to aid dynamic lifting and lowering manual handling tasks. Applied ergonomics, 68, 125-131.

Ishwarya, G. A., \& Rajkumar, D. (2021). Analysis of ergonomic risk factors in construction industry. Materials Today: Proceedings, $37,2415-2418$.

Jasiulewicz-Kaczmarek, M., \& Drożyner, P. (2013, July). Social dimension of sustainable development-safety and ergonomics in maintenance activities. In International Conference on Universal Access in Human-Computer Interaction (pp. 175-184). Springer, Berlin, Heidelberg.

Joshi, M., \& Deshpande, V. (2021). Identification of indifferent posture zones in RULA by sensitivity analysis. International Journal of Industrial Ergonomics, 83,103123 .

Katz, D., Horrell, E., Yang, Y., Burns, B., Buckley, T., Grishkan, A., \& Learned-Miller, E. (2006, August). The umass mobile manipulator uman: An experimental platform for autonomous mobile manipulation. In Workshop on manipulation in human environments at robotics: science and systems. Citeseer.

Kim, W., Peternel, L., Lorenzini, M., Babič, J., \& Ajoudani, A. (2021). A Human-Robot Collaboration Framework for Improving Ergonomics During Dexterous Operation of Power Tools. Robotics and Computer-Integrated Manufacturing, 68, 102084.

Lacomblez, M., \& Teiger, C. (2007). Ergonomia, formações e transformações. Ergonomia.

Laville, A. (2007). Referências para uma história da ergonomia francófona. Ergonomia. Edgard Blucher, 21-32.

Leite, A. L., Silva, C. M., \& Barbosa, R. (2003). Análise ergonômica no processo da extração de calcário laminado: estudo de caso. Encontro Nacional De Engenharia De Produção, 23, 1-7.

Montmollin, M. Vocabulaire de l’Ergonomie. Tolouse, France: Octarès Editions, 2007.

McPhee, B. (2004). Ergonomics in mining. Occupational Medicine, 54(5), 297-303.

Mulder, W., Blok, J., Hoekstra, S., \& Kokkeler, F. (2012). Design for maintenance: guidelines to enhance maintainability, reliability and supportability of industrial products.

Nadri, H., Fasih, F., Nadri, F., \& Nadri, A. (2013). Comparison of ergonomic risk assessment results from Quick Exposure Check and Rapid Entire Body Assessment in an anodizing industry of Tehran, Iran. Journal of Occupational Health and Epidemiology, 2(4), $195-202$.

Nor, N. N., Sunar, M. S., \& Kapi, A. Y. (2020). A Review of Gamification in Virtual Reality (VR) Sport. EAI Endorsed Transactions on Creative Technologies, $6(21)$.

Olszewski, R., Pałka, P., \& Turek, A. (2018). Solving "Smart City" Transport Problems by Designing Carpooling Gamification Schemes with Multi-Agent Systems: The Case of the So-Called "Mordor of Warsaw". Sensors, 18(1), 141.

Paula, A., Haiduke, I. F., \& Marques, I. A. A. (2016). Ergonomia e Gestão: complementaridade para a redução dos afastamentos e do stress, visando melhoria da qualidade de vida do trabalhador. Revista Conbrad, 1(1), 121-136.

Sharan, D. (2012). Ergonomic workplace analysis (EWA). Work, 41(Supplement 1), 5366-5368.

Spada, S., Ghibaudo, L., Gilotta, S., Gastaldi, L., \& Cavatorta, M. P. (2017). Investigation into the applicability of a passive upper-limb exoskeleton in automotive industry. Procedia Manufacturing, 11, 1255-1262. 
Research, Society and Development, v. 10, n. 14, e158101421933, 2021

(CC BY 4.0) | ISSN 2525-3409 | DOI: http://dx.doi.org/10.33448/rsd-v10i14.21933

Qian, G. U. O., Lu, Z. H. A. N. G., Fuyang, Z. H. A. N. G., Shande, L. I. U., \& Nongliang, S. U. N. (2018). Research on ultra-fast laser experiment simulation system based on virtual reality. 实验科学与技术, 16(6), 124-128.

Viteckova, S., Kutilek, P., \& Jirina, M. (2013). Wearable lower limb robotics: A review. Biocybernetics and biomedical engineering, 33(2), 96-105.

Więcek-Janka, E. (2011). Games \& decisions. Publishing House of Poznan University of Technology.

Yamada, Y., Nagasaka, S., \& Morita, T. (2011). Development of weight switching mechanical gravity canceller. Nihon Kikai Gakkai Ronbunshu, C Hen/Transactions of the Japan Society of Mechanical Engineers, Part C, 77(777), 2042-2051. 